\title{
Evaluation of Different Feeding Options for Yearling Arsi Bulls to Attain Export Market Weight
}

\author{
Aman Gudeto, Tesfaye Alemu, Mieso Guru, Ashebir Worku and Genet Dadi \\ Ethiopia Institute of Agriculture Research (EIAR) \\ Oromia Agriculture Research Institute (IQQO), \\ Adami Tulu Agriculture Research Center (ATARC), P.O.Box 35, Zeway, Oromia
}

\begin{abstract}
The study was conducted on station at Agricultural Research Center on Arsi bulls. Twenty four bulls were purchased from the surrounding area. The study objectives were to evaluate and indentify the most economical feeding options for yearling Arsi bulls for them to attain export market weight demand and evaluate the carcass characteristics. Three feeding treatments were evaluated during the feeding period and eight bulls randomly assigned to each of the three treatments. The result of the fattening trial revealed that there is no significant difference in final body weight and carcass characteristics among the bulls received the dietary rations. Furthermore, the study indicated that the yearling Arsi bulls fed on the three dietary rations did not attain export market weight in 238 days of feeding. Therefore, their growth performance should be further evaluated with other feeding options to know their fattening potential. Partial budget analysis of the bulls was not significant difference among the treatments, any of the feeding options can be used depending on availability of the ingredients in the area.
\end{abstract}

Keywords: Yearling Arsi bulls, Market body weight, Carcass characteristic

DOI: $10.7176 / \mathrm{JBAH} / 9-14-01$

Publication date:July $31^{\text {st }} 2019$

\section{INTRODUCTION}

Livestock is an important sector in both highland mixed smallholder farming and low land agro-pastoral systems (Ayeneshet et al., 2018). The sector contributes about $15 \%$ of the total export earnings and $30 \%$ of the agricultural employment. Despite the importance of cattle among the farming communities and to the national economy at large, this sector has remained under-developed and, in many cases, underutilized (Gebretnsae et al., 2017).

The average Ethiopian beef yield per animal of $135 \mathrm{~kg}$ is by far less than $146 \mathrm{~kg}$ for Africa, and $205 \mathrm{~kg}$ for the whole world (Negassa et al., 2011; Yesihak and Webb, 2015; Zekarias, 2016). The total herd off take is estimated at $7 \%$ annually for cattle, 33 and $37 \%$ for sheep and goats, respectively. In Ethiopia, the current per capita consumption of meat is $13.9 \mathrm{~kg} /$ year, being lower than the African and the world per capita averages, which are 27 and $100 \mathrm{~kg} /$ year, respectively (Tsigereda et al., 2016). This is due to the fact that livestock production in Ethiopia is subsistence oriented and characterized by low performance.

Currently, the government is trying to expand sector to meet the increased meat demand from both foreign and domestic markets. However, this could not be fully realized as the traditional livestock fattening practices are not mostly market oriented (Belay and Menale, 2017). Previous effort work regarding fattening of beef cattle at different research centers is less targeted for export market weight demand. To solve the underlying constraints, different demand driven research proposals were developed by different agricultural research institutes to come up with feasible and promising fattening technologies for end users. Evaluation of different breeds and age groups has played a vital role improving body weights and the country's foreign currency earning by exporting meat and live animals (Mieso et al., 2013; Girma et al., 2015; Tesfaye A.T et al., 2017). In this regards, effects of different feeding options for yearling Arsi bulls targeting export market weight demand is not yet studied. Therefore, this study was designed to evaluate and identify most economical feeding options for Arsi cattle bulls to attain export market weight demand $(250-300 \mathrm{~kg})$ and yield quality carcass characteristics.

\section{MATERIALS AND METHODS}

\subsection{Description Study site}

The experimental was conducted at Adami Tulu Agricultural Research Center, which is located in mid rift valley at $167 \mathrm{~km}$ from Addis Ababa, at altitude of $1650 \mathrm{~m}$ above sea level. The agro ecological zone of the area is semi-arid and sub humid with acacia woodland vegetation type. The mean annual rain fall is $760 \mathrm{~mm}$ and its mean minimum and maximum temperatures are 12.6 and $27^{\circ} \mathrm{c}$, respectably.

\subsection{Experimental animals}

A total of twenty four yearling Arsi bulls were purchased from Meki and Bulbula markets of the East Shoa Zone of Oromia Region. Purchased bulls were kept under quarantine in separate barn and they were treated against 
internal and external parasites before the commencement of the fattening trial. All experimental bulls were randomly assigned to one of the three dietary treatment groups.

\subsection{Dietary rations and its ingredients}

Dietary rations were formulated from different feed ingredients, namely molasses, wheat bran, Noug seed cake, maize grain and cotton seed cake. Three dietary rations were formulated in such a way that they contain similar amounts of energy and protein. The rations were:

1. Rhodes grass hay $+20 \%$ molasses $+40 \%$ wheat bran $+40 \%$ Noug seed cake,

2. Rhodes grass hay $+20 \%$ maize grain $+45 \%$ wheat bran $+35 \%$ Noug seed cake and

3. Rhodes grass hay $+35 \%$ cotton seed cake $+65 \%$ wheat bran. DM, total CP and TDN content of the experimental feeds are depicted in Table 1.

Table 1: Ingredients and chemical composition of the dietary rations

\begin{tabular}{lllll}
\hline Dietary ration & Ingredient & DM\% & CP\% & TDN\% \\
\hline \multirow{3}{*}{$\mathrm{T}_{1}$} & Molasses $(5.8,72)$ & 20 & 1.16 & 14.40 \\
& Wheat bran $(13,67)$ & 35 & 5.52 & 26.80 \\
& Noug seed cake $(27,72)$ & 45 & 11.9 & 26.40 \\
& Total & $\mathbf{1 0 0}$ & $\mathbf{1 8 . 5 8}$ & $\mathbf{6 7 . 6}$ \\
\hline \multirow{3}{*}{$\mathrm{T}_{2}$} & Maize grain $(10,85)$ & 20 & 2.00 & 17.00 \\
& Wheat bran $(13,67)$ & 45 & 5.85 & 30.15 \\
& Noug cake $(29.75,66)$ & 35 & 10.41 & 23.10 \\
\hline \multirow{2}{*}{$\mathrm{T}_{3}$} & Total & $\mathbf{1 0 0}$ & $\mathbf{1 8 . 2 6}$ & $\mathbf{7 0 . 2 5}$ \\
& Wheat bran $(13,67)$ & 65 & 8.45 & 43.55 \\
& Cottonseed cake $(28,75)$ & 35 & 9.80 & $\mathbf{1 8 . 2 5}$ \\
\hline
\end{tabular}

$T=$ Treatment, $D M=$ Dry matter, $C P=$ Crude protein, $T D N=$ Total digestible nutrient

\subsection{Feeding the experimental bulls}

Grass hay was provided adlibtum for all the experimental animals. Every day, all bulls were supplemented with concentrate feeds at the rate of $2.5 \%$ of their body weight throughout the fattening period. The amount of feed offered for bulls were adjusted every two weeks depending on weight change during feeding period. All experimental animals were individually fed with their corresponding rations for 21 days of adaptation and 238 days of feeding. Daily allocated feed per bull was divided into two equal amounts and offered twice per day, half in the morning and the remaining half in the afternoon.

\subsection{Growth performance calculation formula}

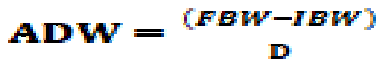

$\mathrm{TWG}=\mathrm{FBW}-\mathrm{IBW}$

Where: $\quad \mathrm{ADG}=$ Average daily weight gain, $\mathrm{TWG}=$ Total weight gain, $\mathrm{FBW}=$ Final body weight, $\mathrm{IBW}=$ Initial body weight and $\mathrm{D}=$ Total of fattening days

\subsection{Carcass characteristics}

At the end of the fattening period, nine bulls were slaughtered at Adami Tulu Agriculture Research Center slaughter house then the animals were skinned, all important internal organs such as kidney, heart, liver, lung, spleen, empty gut, heart fat, kidney fat, mesenteric and omental fat were eviscerated and the required carcass parameters were individually measured. The hot carcass was dissected symmetrically into right and left part. The right side carcass was set into cold chill room at $-4^{\circ} \mathrm{c}$ for 24 hours, after which the carcass was measured again to evaluate the difference in weight change between hot and cold carcass of each slaughtered bull. To evaluate the chilled carcass characteristics, the right part of each slaughtered bull was cut into five major carcass parameters.

\subsection{Partial budget analysis}

All variable costs incurred in conducting the trial were recorded. Total variable costs such as animal purchase, transportation, feeds, labor and veterinary costs were included in partial budget analysis. At the end of the fattening period, the gross output/revenues were obtained from prices of the bulls as estimated by the help of people who have enough knowledge on the prices of fattened animals. Fixed costs incurred for feeding the animals were not included in cost benefit analysis. 


\subsection{Statistical analysis}

Data on all live weights and carcass parameters were analyzed using the general linear model (GLM) of Statistical Analysis System (ver. 8). The estimated least squares means were separated using the Duncan's Multiple Range Test at $P<0.05$.

\section{RESULTS AND DISCUSSION}

\subsection{Effect of dietary rations on growth performance}

Growth performances of the experimental bulls were analyzed at 60 days, 120 days and 238 days of fattening period. Final body weight, total and average daily weight gains of the bulls on these days are depicted in Table 2.

Table 2: Effect of dietary rations on growth performance of the bulls in each treatment

\begin{tabular}{|c|c|c|c|c|}
\hline Fattening days & Weight & $T_{1}$ & $\mathbf{T}_{2}$ & $T_{3}$ \\
\hline First day & IBW (kg) & 106.8 & 106.2 & 108.3 \\
\hline \multirow{3}{*}{60 days } & FBW (kg) & $155.4 \pm 4.7$ & $158.7 \pm 4.6$ & $156.6 \pm 4.6$ \\
\hline & TWG (kg) & $48.5 \pm 2.7$ & $52.5 \pm 2.7$ & $48.3 \pm 2.7$ \\
\hline & $\operatorname{ADG}(\mathrm{g})$ & $866.8 \pm 48.3$ & $937.5 \pm 48.4$ & $862.3 \pm 48.3$ \\
\hline \multirow{3}{*}{120 days } & FBW (kg) & $202.1 \pm 5.2$ & $201 \pm 5.6$ & $185.5 \pm 5.2$ \\
\hline & TWG (kg) & $95.2 \pm 3.1^{\mathrm{a}}$ & $96.8 \pm 3.3^{\mathrm{a}}$ & $77.1 \pm 3.1^{\mathrm{b}}$ \\
\hline & $\operatorname{ADG}(\mathrm{g})$ & $618.5 \pm 20.3^{\mathrm{a}}$ & $628.9 \pm 21.7^{\mathrm{a}}$ & $500.8 \pm 20.3^{\mathrm{b}}$ \\
\hline \multirow{3}{*}{238 days } & FBW (kg) & $239.7 \pm 6.5$ & $239 \pm 6.9$ & $220.2 \pm 6.5$ \\
\hline & TWG (kg) & $132.8 \pm 4.8^{\mathrm{a}}$ & $134.8 \pm 5.1^{\mathrm{a}}$ & $111.8 \pm 4.8^{\mathrm{b}}$ \\
\hline & $\operatorname{ADG}(\mathrm{g})$ & $558.3 \pm 20.2^{\mathrm{a}}$ & $566.6 \pm 21.6^{\mathrm{a}}$ & $470.1 \pm 20.2^{\mathrm{b}}$ \\
\hline \multicolumn{5}{|c|}{$\begin{array}{l}I B W=\text { Initial body weight, } F B W=\text { Final body weight, } A D G=\text { Average daily weight gain, } T W G=\text { Total weight } \\
\text { gain }\end{array}$} \\
\hline \multicolumn{5}{|c|}{$\begin{array}{l}\text { The results show that there is no statistically significance difference in final body weight at all the three } \\
\text { weighing days among the three treatments }\left(\mathrm{T}_{1}, \mathrm{~T}_{2} \& \mathrm{~T}_{3}\right) \text {. This is similar to the finding of Mieso et al., (2013) } \\
\text { who conducted similar study on the yearling Borana bulls. Similarly, Girma et al., (2015) reported that the three } \\
\text { dietary rations have similar effect on final body weight of two years old Borana bulls. Total and average daily } \\
\text { weight gains of these yearling Arsi bulls were significantly different among the three treatments at } 238 \text { days of } \\
\text { fattening. In previous studies (Mieso et al., 2013; Girma et al., 2015; Tesfaye A.T. et al., 2017) conducted on } \\
\text { yearling Borana bulls, two years old Borana and Kereyu bulls fed similar dietary ration, no significant } \\
\text { differences were reported in total weight gains among the treatment groups. } \\
\text { The current average daily weight gains of these Arsi bulls at the end of the fattening period is less than the } \\
\text { finding of Girma et al., (2015) who reported a daily weight gain of } 777 \text { g/day for Borana bulls in } 224 \text { days of } \\
\text { fattening period. Furthermore, this study indicated that the yearling Arsi bulls did not attain export market body } \\
\text { weight demand in } 238 \text { days of fattening period. However, yearling Borana bulls which were fed similar diets } \\
\text { reached export market body weight demand within } 224 \text { days of fattening (Mieso et al., 2013). This difference } \\
\text { may be attributed to naturally short skeletal dimension of Arsi cattle than Borana cattle breed. }\end{array}$} \\
\hline
\end{tabular}

\subsection{Effects of dietary feeds on carcass components}

The result of carcass evaluation of the bulls fed on the three different feed rations is illustrated in Figure1. In this trial, there were no significant differences in hot carcass and cold carcass among the three treatments. However, the carcass weight of bulls assigned to treatment one was higher than that of the other teatments. This finding was similar to the finding of Tesfaye A.T. et al., (2017) for two years old kereyu breeds fed the same dietary rations. Furthermore, hot carcass weight of the expermental bulls was slghtly higher than that of the cold carcass. 


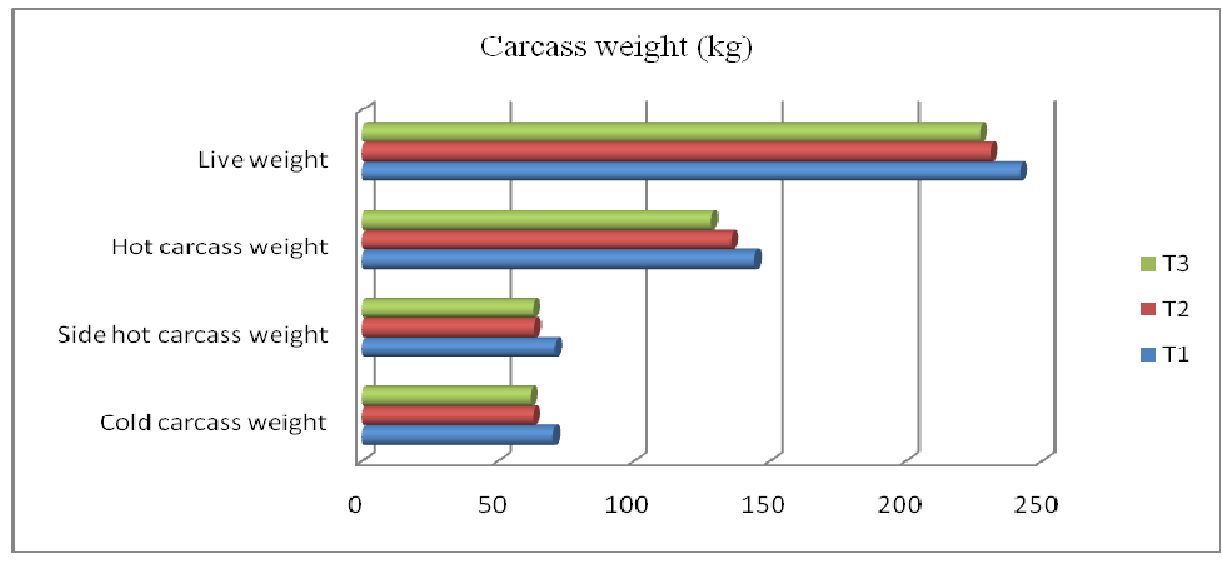

Figure 1: Carcass weight of yearling Arsi bulls

\subsection{Effects of dietary feeds on edible organs and dressing percentage}

Effects of the dietary rations on edible organs of the slaughtered bulls are indicated in Table 3 . The mean weights of edible organs of the bulls are not significantly different among the bulls fed the three dietary rations. This result may associated with the fact that the bulls received the same percentage of total CP and TDN which might have the same effect on carcass characteristics of the bulls. This finding is similar with what is reported by Mieso et al., (2013) for one year-old Borana bulls, by Girma et al., (2015) for two years old Borana bulls and by Tesfaye A.T. et al., (2017) for two years-old Kereyu bulls.

The dressing percentages of these bulls was comparable to the dressing percentage of two years old Kereyu bulls $(56.3 \%)$, Ogaden bulls (56\%) but slightly lower than that of the two years old Borana bulls $(61 \%)$ reported by Tesfaye A.T. et al., (2017), Yosep et al., (2011) and Girma et al., (2015), respectively. Though there was no statistical difference, the dressing percentage of bulls in treatment one was higher than that of the bulls in treatment two and three.

Table 3: Effects of different feeding options on edible organs of the bulls $(\mathrm{kg})$

\begin{tabular}{llll}
\hline Carcass parameters & $\mathbf{T}_{\mathbf{1}}$ & $\mathbf{T}_{\mathbf{2}}$ & $\mathbf{T}_{\mathbf{3}}$ \\
\hline Tongue & $0.83 \pm 0.08$ & $0.81 \pm 0.08$ & $0.83 \pm 0.1$ \\
Heart & $0.9 \pm 0.06$ & $0.85 \pm 0.064$ & $0.78 \pm 0.1$ \\
Heart fat & $0.9 \pm 0.16$ & $0.8 \pm 0.16$ & $0.7 \pm 0.16$ \\
Kidney & $0.5 \pm 0.02$ & $0.45 \pm 0.02$ & $0.45 \pm 0.02$ \\
Liver & $3.7 \pm 0.2$ & $3.8 \pm 0.23$ & $3.4 \pm 0.22$ \\
Hump & $4.9 \pm 0.49$ & $3.9 \pm 0.5$ & $5.1 \pm 0.4$ \\
Empty Gut & $6.4 \pm 0.43$ & $4.7 \pm 0.4$ & $5.8 \pm 0.43$ \\
Dressing \% & 59.6 & 58.8 & 56.4 \\
\hline
\end{tabular}

\subsection{Partial budget analysis}

Table 4: Partial budget analysis of fattening yearling Arsi bulls

\begin{tabular}{lllll}
\hline List of items & $\mathbf{T}_{\mathbf{1}}$ & $\mathbf{T}_{\mathbf{2}}$ & $\mathbf{T}_{\mathbf{3}}$ & Overall \\
\hline Feeds costs per bull (ETB) & 8825 & 9250 & 9100 & 9058.333 \\
Purchasing price per bull(ETB) & 3000 & 3000 & 3000 & 3000 \\
labor cost per bull(ETB) & 694.2 & 694.2 & 694.2 & 694.2 \\
Vet cost per bull (ETB) & 93 & 93 & 93 & 93 \\
Total variable cost per bull(ETB) & 12612.2 & 13037.2 & 12887.2 & 12845.53 \\
Total gross output per bull(ETB) & 16500 & 16500 & 16000 & 16333.33 \\
Gross margin per bull(ETB) & 3887.8 & 3462.8 & 3112.8 & 3487.8 \\
\hline Total gross margin (ETB) & $\mathbf{3 1 1 0 2 . 4}$ & $\mathbf{2 7 7 0 2 . 4}$ & $\mathbf{2 4 9 0 2 . 4}$ & $\mathbf{2 7 9 0 2 . 4}$ \\
\hline
\end{tabular}

\section{ETB=Ethiopia birr}

The result of partial budget analysis of fattening the yearling Arsi bulls is given in Table 4. The analysis indicates higher gross margin per animal (31102.4 ETB) for experimental bulls fed dietary feed one than those fed dietary feed two (27702.4 ETB) and dietary ration three (24902.4 ETB). The results are similar with the results obtained from partial budget analysis of feeding two years old Borana bulls (Girma et al., 2015). The bulls fed treatment three diet were less profitable as compare to those fed treatment one and two diets. 


\section{CONCLUSION}

Twenty four yearling Arsi bulls were randomly assigned for three dietary rations and kept on feeding for 238 days. Growth performances of the bulls were assessed during the fattening period. There is no statistically significant difference in final body weight and in the most of the carcass characteristics which may be correlated with similarity of the bulls both in breed and age. Moreover, the same percentage of total CP and TDN were provided for all the experimental bulls. The yearling Arsi bulls did not attain export market weight in 238 days of feeding. Hence it needs to see other feeding options that would enable the bulls to attain the export market body weight demand in the shortest possible fattening period. However, numerically bulls fed on ration one are more profitable than bulls fed on rations two and three. Therefore, any beef cattle fatteners can preferably use feeding treatment one to fatten yearling Arsi bulls for local markets. However, as there were no significant differences in major parameters among the treatments, any of the feeding treatments can be used depending on the availability of the feed ingredients in the targeted area.

\section{ACKNOWLEDGMENTS}

The authors are grateful to Ethiopia Institute of Agriculture Research, for providing funds for the experiments. We are very grateful to Oromia Agriculture Research Institute for creation linkage between Ethiopia institute of Agriculture Research and Adami Tulu Agriculture Research Centre. We would like to extend our appreciation to Adami Tulu Agriculture Research Centre for technical support us during conducting study.

\section{COMPETING INTERESTS}

Authors have declared that no competing interests exist.

\section{REFERENCES}

[1] Ayeneshet B, Abera M and Wondifraw Z. (2018). Reproductive and Productive Performance of Indigenous Dairy Cows under Smallholder Farmers Management System in North. Journal of Fisheries \& Livestock Production. 6(1): 1-5

[2] Belay Zeleke and Minale Getachew (2017). Traditional Cattle Husbandry Practice in Gamo Gofa Zone, Southern Western Ethiopia. International Journal of Novel Research in Life Sciences 4(5): 1-7.

[3] Gebretnsae Mezgebe, Solomon Gizaw, Mengistu Urge and Arvind Chavhan (2017). Begait cattle production systems and production performances in northern Ethiopia. Int. J. of Life Sciences. 5 (4): 506-516

[4] Girma D, Mieso G, Tesfaye A, Arse G, Frehowit M, Ashebir W and Aman G. (2015). Effect of different feeds option on growth response and carcass characteristic of two years aged Borana bulls for export market weight gain at Adami Tulu Agricultural Research Center. Basic Research Journal of Agricultural Science Vol. 4(5) pp. 139-145

[5] Mieso Guru, Girma Debele, Tesfaye Alemu Tucho, Frihiwot Messele and Tesfaye Alemu Aredo. 2013. Evaluation of different feeding options on yearling Borana bulls to attain export market weight at Adami Tulu Agricultural Research Center. American Journal of Cell and Animal Biology Vol. 1, No. 1, PP: 01 -09

[6] Negassa, A., Shahidur, R. and Gebremedhin, B. 2011. Livestock Production and Marketing in Ethiopia. Ethiopia Strategy Support Program II, ESSP II Working Paper, pp: 26-35.

[7] Tesfaye A.T., Tesfaye A.A., Girma D., Mieso G. , Ashebir W., Aman G. and Frehowit M (2017). Effect of different feeds option on growth response and carcass characteristic of two years aged Kereyu bulls for export market weight gain at Adami Tulu agricultural Research Center. In annual completed research proceeding of Oromia Agricultural Research Institute (OARI) held at Batu, Oromia.

[8] Tsegay Teklebrhan, Mengistu Urge (2013). Assessment of commercial feedlot finishing practices at Eastern Shoa, Ethiopia. Open Journal of Animal Sciences, Vol.3, No.4, 273-280

[9] Yesihak Y.M. \& Webb E.C. 2015. Causes of Beef Carcass and Organ Condemnations in Ethiopia. Asian Journal of Animal and Veterinary Advances, 10(4), 147-160.

[10] Yosep Mekasha, Mengistu Urge, Mohammed Y. Kurtu and Merga Bayissa .2011. Effect of strategic supplementation with different proportion of agro-industrial by-products and grass hay on body weight change and carcass characteristics of tropical Ogaden bulls grazing native pasture. African Journal of Agricultural research Vol. 6(4), pp. 825-833

[11] Zekarias Bassa, Shewangizawu Wolde, Tesfaye Alemu, Melese Yilma, Asrat Terra, Berekt Zeleke and Deibe Gemiyu. 2016. Evaluation of Locally Available Energy Source Feeds on Fattening Performance of Local Oxen and Carcass Analysis in Wolaita, Southern Ethiopia. Hydrol Current Res 7:255. doi: 10.4172/2157-7587.1000255. 